Comptes Rendus Palevol

Volume 11, Issue 4, May-June 2012, Pages 305-313

https://doi.org/10.1016/i.crpv.2011.11.001

\title{
Multi-millennial occupation in northwestern Laos: Preliminary results of excavations at the Ngeubhinh Mouxeu rock-shelter
}

\section{Occupation multimillénaire dans le Nord-Ouest du Laos : résultats préliminaires de la fouille de l'abri-sous-roche Ngeubhinh Mouxeu}

\author{
Valéry Zeitoun
}

UMR 9993, musée Guimet CNRS, 19, avenue d'İ̀na, 75116 Paris, France

Hubert Forestier

UMR 208, IRD-Mnhn, 32, rue Varagnat, 93143 Bondy, France

Alain Pierret

IRD, UMR 211 Bioemco, 32, rue Varagnat, 93143 Bondy, France

Chantalpilith Chiemsisouraj

Institut d'histoire de l'Académie Lao des Sciences Sociales, Muong Chanthaboury, Ban Sibounheuang, unité 30, batiment 407, BP 7195, Vientiane, Laos DPR

Mien Lorvankhamd, Amthilor Latthagnotd, Tammalay Chanthamoungkhound, Sèngphet Norkhamsomphou

Ministère de l'Information, de la Culture et du Tourisme, division des fouilles archéologiques, département du Patrimoine, rue Setthathirath, Vientiane, Laos DPR

\begin{abstract}
With over half a century of political instability, resulting from armed conflicts, decolonisation and the Cold War, archaeological investigations in Laos have been rare, leaving little more than a blank page in the chapter of Southeast Asia's prehistory. Recent research has shown that Laos holds a rich prehistoric heritage. In conjunction with the research initiated by J. White who conducted the first professional archaeological survey of northern Laos since decades, we have extended the investigations to the Luang Namtha province. This work allowed us to gather important data about Hoabinhian stone tool assemblages and former cultures. In particular, the archaeological remains and dating from the Ngeubhinh Mouxeu rock-shelter indicate that this mountainous region of Laos has been inhabited over a long period of time that possibly spans as far back as $56,000 \pm 3000 \mathrm{BP}$.
\end{abstract}

\section{Résumé}

En raison d'une instabilité géopolitique d'un demi-siècle, les investigations archéologiques au Laos ont été rares, ne laissant qu'une page blanche au chapitre de la Préhistoire de l'Asie du Sud-Est. De récentes recherches ont mis en évidence un riche héritage préhistorique. En conjonction avec les recherches initiées par J. White qui dirigea les premières prospections archéologiques professionnelles du Nord-Laos depuis des décennies, les investigations ont été étendues jusqu’à la province de Luang Namtha. Ce travail nous a permis de rassembler d'importantes données sur les vestiges archéologiques et la datation de l'abri-sous roche Ngeubhinh Mouxeu indiquent que cette région montagneuse du Laos a été habitée sur une longue période remontant probablement à $56000 \pm 3000$ ans BP.

\section{Introduction}

The few archaeological investigations that have been conducted in Laos between the end of the 19th century and the second World War include the collection of polished stones and metallic implements in Luang Prabang province, collected during the "Mission Pavie" (1879-1895) (Massie, 1904); an archaeological survey and the excavation of Ban Don Tio cave, undertaken by Mansuy in the early 20th century (Mansuy, 1920); operations conducted by the Geological Service of Indochina during the French Indochina period (Fromaget, 1934, 1937a, 1937b, 1940b, 1941, 1952). Over this period, Fromaget, Saurin and Colani have certainly been the most active and productive researchers involved in archaeological work in the region (Arambourg and Fromaget, 1938; Colani, 1932, 1935; Fromaget, 1936, 1937a, 1937b, 1940a, 1952; Fromaget and Saurin, 1936; Saurin, 1935, 1966, 1968). Although some of the prehistoric sites discovered between the 1930s and the late 1960s have been re-visited and further described (Sayavongkhamdy et al., 2000), the 
revival of prehistory in Laos really only started in 2005, with the Middle Mekong Archaeological Project led by J. White (Marwick et al., 2009). This exploratory survey of the Luang Prabang area resulted in the discovery and excavation of the Phou Phaa Khao rock-shelter and Tham Vang Ta Leow cave, which have yielded an original Hoabinhian industry (White and Bouasisengpaseuth, 2008). In this article, we report the early results of a survey conducted in the vicinity of Vieng Phu Khra, Luang Nam Tha province (Northwestern of Laos) in 2010, within the framework of a partnership between the Institut de Recherche pour le Développement (IRD), the Laotian Department of History of the National Academy of Social Sciences and the Laotian Department of Archaeology of the Ministry of Culture and Communication. The overarching aim of this regional, interdisciplinary project was to document the ethnographic, environmental and archaeological modalities of landscape management and settlement by human communities, from prehistoric times to the present. This survey allowed us to find a prehistoric site where a long-term sequence of human occupation has been identified. This finding, which includes several types of cultural remains, is important and rare enough in Southeast Asia to be described with some degree of detail because it contributes to filling the blank page of Laotian archaeology.

\section{Materials and methods}

The Ngeubhinh Mouxeu rock-shelter (N 20॰42.98', E 101॰ 00.96’) is located $7 \mathrm{~km}$ northwest of Vieng Phu Khra, between the villages of Ban Nam Kaab Neua and Ban Nam Kaab Tay, to the north and south, respectively, at an elevation of $846 \mathrm{~m}$ above sea level (Fig. 1). These two villages are currently inhabited by a mixed population of Lamet, $\mathrm{Khmu}$, and Mouxeu ethnics, the latter being the dominant ethnic group. There are 292 and 383 inhabitants in the northern and southern villages, respectively.

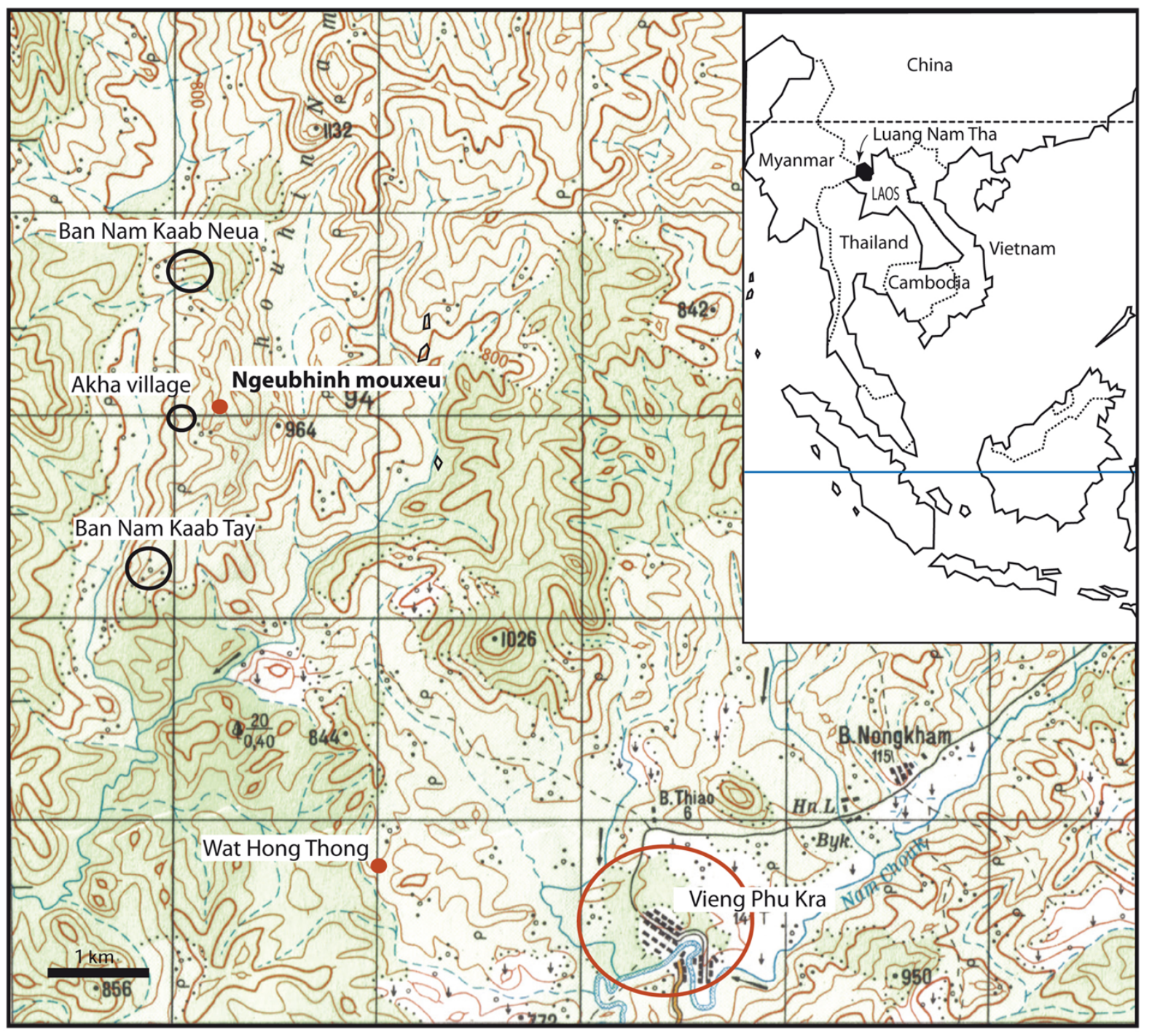

Fig. 1. Location of Ngeubhinh Mouxeu rock-shelter. 
During our archaeological investigations, an Akha village of about 90 inhabitants was being settled downhill from the rockshelter and the new settlers were slashing and burning the forest near the excavations site. Inspected on the occasion of a field survey in the Vieng Phu Khra region (Louang Namtha province), the rock-shelter was excavated following the identification of stone tool implements on the soil surface. In its widest dimensions, the rock-shelter is approximately $21 \mathrm{~m}$ long and $12 \mathrm{~m}$ wide (Fig. 2). Under the roof, the soil surface follows a slope of about $10 \%$ with a southward pitch. After recording the topography of the site, the archaeological excavation consisted of digging a $5^{\circ} \varnothing 1 \mathrm{~m}$ wide trench, with a mean depth of $1.5 \mathrm{~m}$.
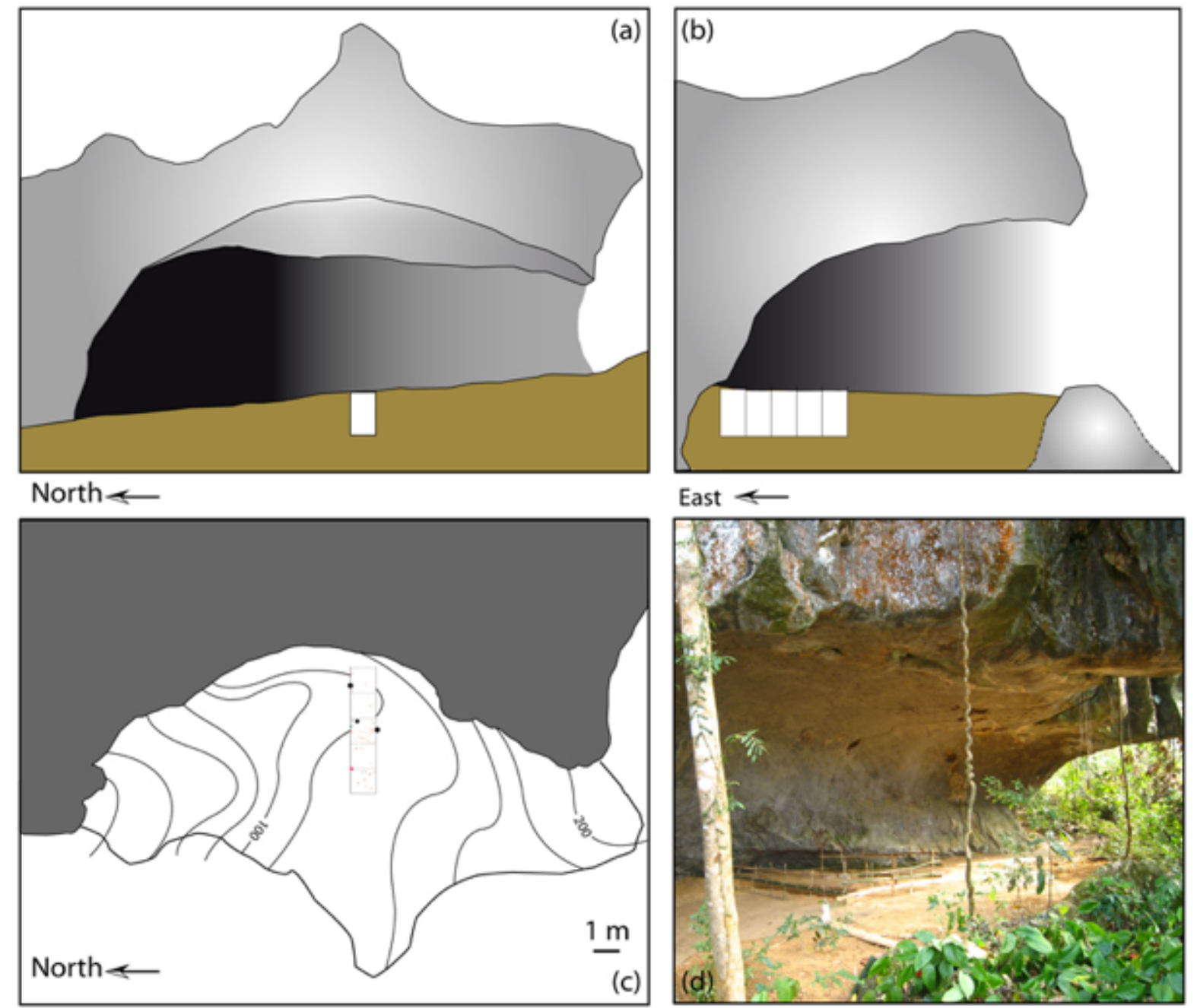

Fig. 2. Ngeubhinh Mouxeu rock-shelter: a: frontal view of the rock-shelter; b: lateral view of the rock-shelter; c: topography of the floor of the rock-shelter; d: view of the rock-shelter.

\section{Stone tools}

The lithic material collected during the excavation was not abundant but allowed a precise diagnosis of the stone industry. Overall, the stone flakes brought to light are informative about the pre-Hoabinhian and Hoabinhian systems of lithic production. To date, in Laos, there has been a paucity of such lithic material in stratigraphic position; our findings therefore represent a new chronocultural milestone for the prehistory of northern Laos. The Hoabinhian is a common lithic faciès found throughout Southeast Asia, from Vietnam to Thailand, and from southern China to the North of Sumatra, and is generally attributed to hunter-gatherer societies that occupied the region from approximately 30,000 to 3000 BP. Very little is known about these cultures in northern Laos and to date, there hardly exists any other reports of similar findings in a precisely documented archaeological context (Sayavongkhamdy et al., 2000; White et al., 2009). Consequently, the lithic material uncovered at the Ngeubhinh Mouxeu rock-shelter represents, in many respects, an important step for the advancement of the local prehistory: first, it documents the economy of raw materials used for producing stone tools (choice, quality, morphology, acquisition, strategy and management of a territory); second, it provides information on the modes of knapping (shaping or débitage 
of hard rock); and third, it provides hints of the various types of tools looked for by knappers. The lithic material collected during the excavation provided evidence for the existence of different types of tools and showed that there were at least two different prehistoric occupations during the Recent Pleistocene. The more ancient occupation period corresponds to a pre-Hoabinhian context while the more recent one is typical of the Hoabinhian faciès. The most ancient occupation was stratigraphically identified and could be dated, whereas the Hoabinhian occupation could only be ascertained based on the presence of tools in colluvions and on the rock-shelter's floor, next to the perimeter of the excavation.

\section{The pre-Hoabinhian material}

Whereas the Hoabinhian tools were systematically made from river cobbles shaped into heavy, multifunctional tools (Forestier, 2000) similar to the archetypical unifacial sumatraliths, the pre-Hoabinhian lithic industry of the Ngeubhinh Mouxeu site was derived from a whitish-yellowish chert; this raw material is an opaque flint with a matte surface, with fairly good properties for knapping. This siliceous material was most likely extracted from blocks such as those that can be seen in the karstic surroundings of the rockshelter. These pre-Hoabinhian lithic remains are flakes which suggests the existence of core reduction activities at the site. However, no evidence of shaping was found in contrast with classic Hoabinhian industries. Nine chert-made objects were discovered during the excavation. These were either simple shipped flakes with smooth butts or butts broken during knapping, or tools on flakes (Fig. 3). These flakes, 4 to $12 \mathrm{~cm}$ in size, were produced by means of direct percussion with a hard hammer. The largest pieces had a thick, triangular section. The heterogeneity of observed morphologies of these supports is indicative of a short chaîne opératoire characterised by a poor knapping control and a simple débitage of flakes from unprepared cores. The knappers' priority must have been the rapid production of supports while looking
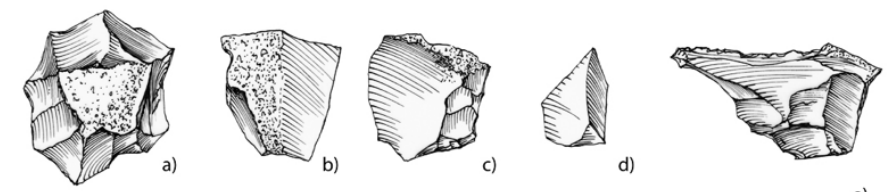

d)

e)
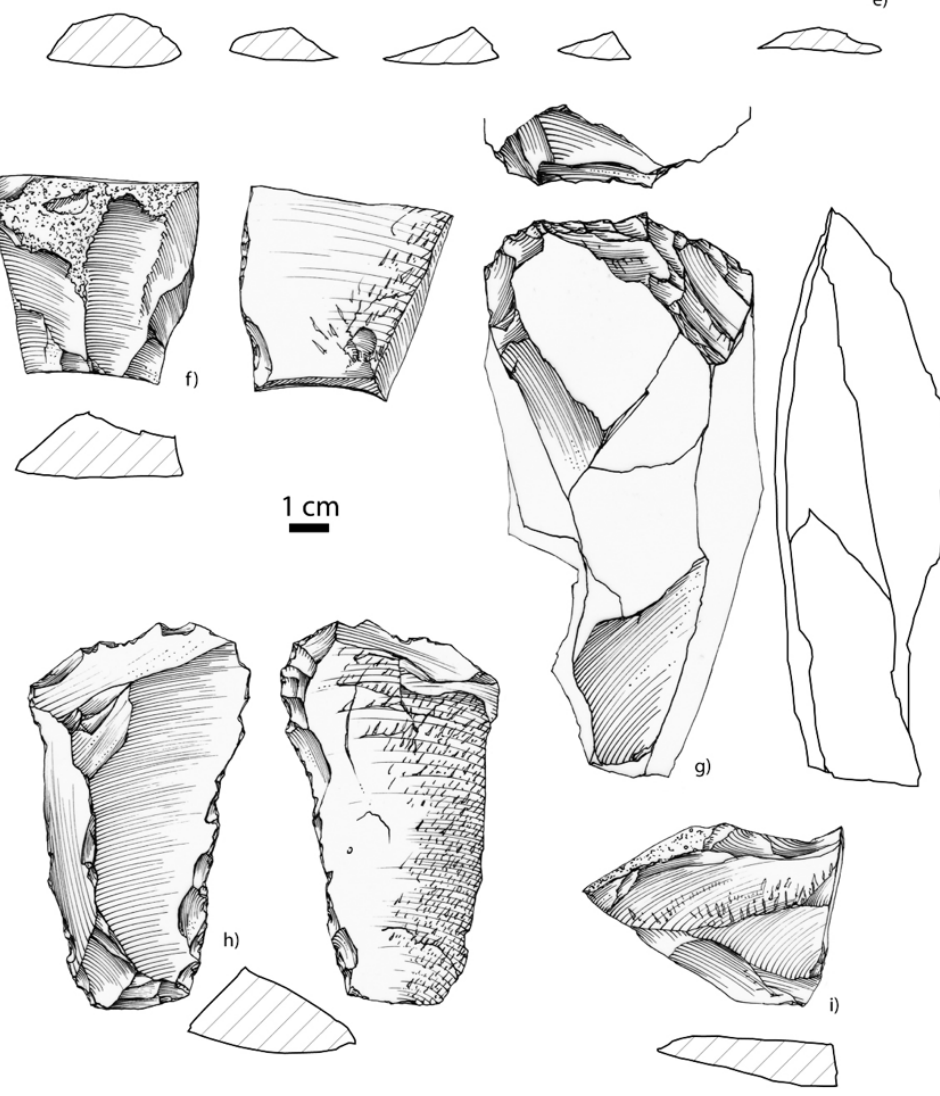

for the elongation of products, without any specific or careful preparation of the original block. The small flakes thus produced were used without modification. Flakes of larger dimensions with a triangular or trapezoidal section, and with a thick back, were transformed into either lateral denticulated tools, thick end cutting edge or thick end-scrapers, using a common and steep retouching. The variability of the flake morphology suggests an absence of standardisation even though a certain organisation of the core reduction existed. In the absence of any core, it remains difficult to infer the knapping method. However, judging from flake morphologies and negatives of removals on their upper faces, it can be said that a simple knapping method, with a broadly unipolar alternating platform system, was most likely used. The presence of cortex on the upper faces of flakes indicates that the chaine opératoire was short.

Fig. 3. Pre-Hoabinhian stone tools: a, b, c, d and i: cortical and non-cortical flake; e: transversal micro denticulate; f: notch; h: lateral denticulate with an ordinary alterning retouch; g: thick end scraper. 


\section{Hoabinhian material}

Four Hoabinhian tools on cobble (Fig. 4) were found on the rock-shelter's floor near the excavation. The raw material used for this industry consists of calcareous stone cobbles about $10 \mathrm{~cm}$ in length, collected in the bed of the river that encircles the limestone hill at the top of which the rock-shelter opens. However, the global morphology of the cobbles was not uniformly of oval, elongated "standard" shape nor of natural planoconvex section, as is frequently the case in the stone tool assemblages of Southeast Asia (Forestier, 2000; Moser, 2001; Zeitoun et al., 2008). Two out of four tools were made from relatively thick, wide, elongated and rather quadrangular morphologies. One out of the four tools was an original convergent tool (Fig. 4a). This object, sharpened at one of its extremities, was entirely shaped by means of a covering retouch on a single face. It was made thinner by an invasive secondary retouch at the level of the convergent edges, where on the right edge, the knapper exploited a break. The cortical part is not very wide and voluntarily left as such: it may be interpreted as the prehensile proximal part of the tool. The tool (Fig. $4 \mathbf{b}$ )
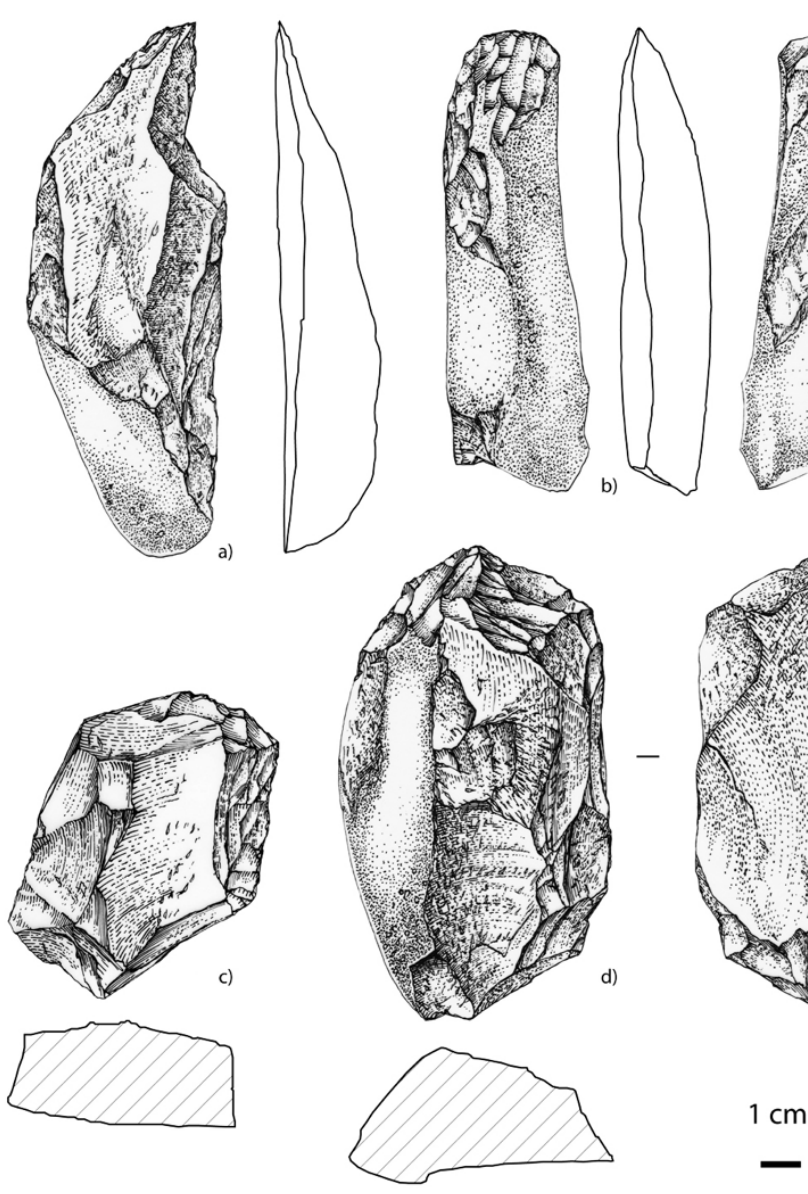

\section{Ceramic material}

Apart from one almost complete pottery, the ceramic material found during the excavation (Figs. $\mathbf{5}$ and $\mathbf{6}$ ) consists of very small fragments weighing only a few grams each. Nevertheless, considering clay colour, thickness, and surface treatment, this material has been classified into four different categories. The first set contains one isolated sherd found on the shelter's floor. It is a sherd $6 \times 5 \times 0.6 \mathrm{~cm}$ in dimensions, bearing incised marks. The orange clay shows millimetric mineral temper. The black inner surface has been smoothed (Fig. 5a). The second category includes four isolated sherds. The orange clay is rough with clearly visible millimetric to sub-millimetric mineral temper on the inner surface. The external brownish-coloured surface bears corded ornamentation, probably made by imprinting the fibrous design of a rope wound around a paddle. The largest such sherd is $5 \times 5 \times 0.6 \mathrm{~cm}$ (Fig. 5b). The third category includes 24 sherds and eight rims belonging to a unique cylindrical vessel (upper diameter $18 \mathrm{~cm}$ ) with straight everted rims. The clear orange clay contains a calcitic temper. The black pottery is smoothed on both surfaces showing horizontal parallel lines. The mean thickness ranges from 1 to $2 \mathrm{~cm}$ at the external part of the rim. The overall weight of this vessel is of about $600 \mathrm{~g}$ (Fig. 6a). 

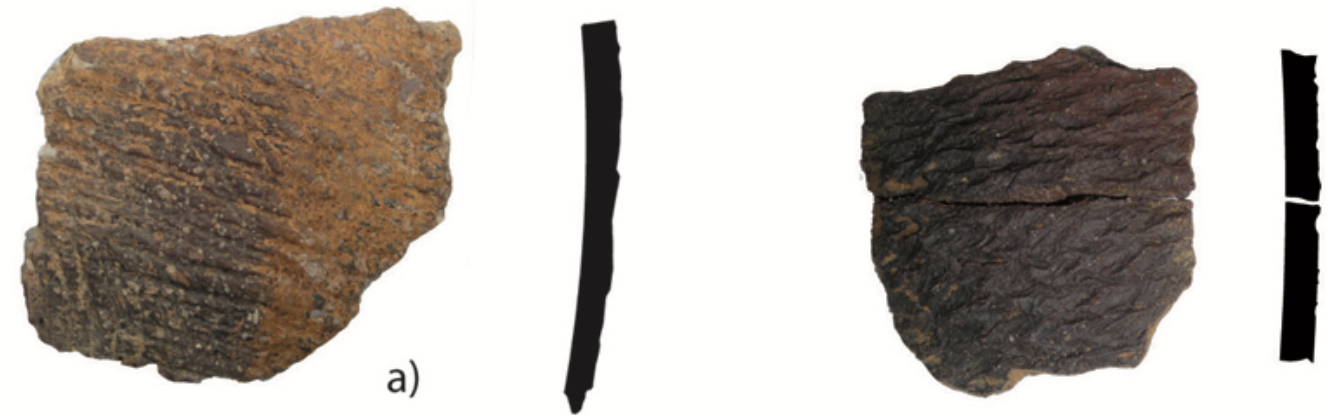

b)

\section{$1 \mathrm{~cm}$}

Fig. 5. Ceramic remains: a: incised decorated sherd; b: cord-marked decorated sherd.

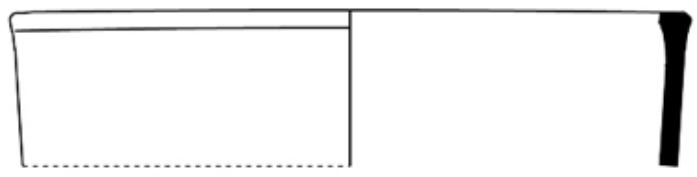

a)

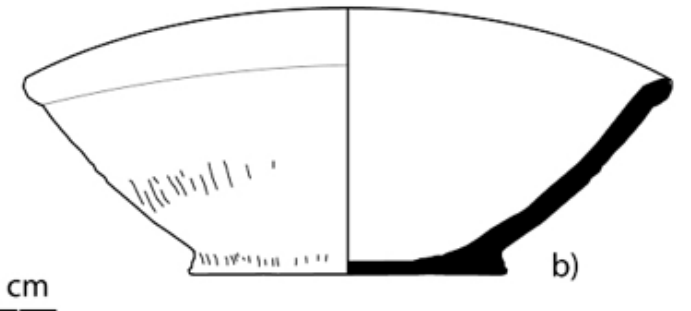

Fig. 6. Vessels: a: cylindrical vessel with straight rim; b: incised decorated bowl.

The fourth category is a broken bowl weighing $360 \mathrm{~g}$. The orange clay includes calcitic mineral temper. The outer diameter is $17 \mathrm{~cm}$ at the top and $8 \mathrm{~cm}$ at the bottom. The bowl is incised on its external surface (Fig. 6b). In all four ceramic categories, the clays contain a mineral temper and the firing is fair to poor. Comparative elements for pottery categories do not exist in Laos and the described categories are commonly found at most Southeast Asian prehistoric sites. Cord-marking and fine incised technique are characteristic decoration of Neolithic and Iron Age pottery in Southeast Asia, while the use of the paddle is very common from Neolithic to the present day (Van Tan, 1985). After the in-depth filling of the original karstic cavity by fine clayey sediments, racking of these levels towards the outside of the cavity happened once the embedding limestone started to crack and collapse (Fig. 7). This phenomenon occurred before and during the cave opening. Collapsed ceiling blocks outside the rock-shelter have only partially held the original sediment in place, and a large proportion of it was lost by erosion. This eroded surface was then sealed by sediments containing gravel and inclusions of the previously deposited clay. The pre-Hoabinhian stone tools were collected from this mixed matrix dated between $56,000 \pm 3000 \mathrm{BP}$ and $45,000 \pm 2000 \mathrm{BP}$ by OSL by the Laboratory of luminescence dating of the Korean Basic Science Institute of Yang Cheong (Fig. 8). A later phase which was not directly identified in stratigraphy is comparable to Hoabinhian from the technological point of view (stone tools collected on the rock-shelter's soil, towards its highest and lowest points). The third archaeological phase suggests the use of the rock-shelter for temporary settlement or funerary activities, as indicated by the presence of a poorly shaped bowl associated with finely fragmented remnants of human bones. No faunal remains were discovered during the excavation; and the Recent human bones were only splinters, which suggests a particular taphonomy with a very corrosive soil context. A perturbed sedimentary level is present. The limits of this level were sealed by a chemical accumulation/precipitation of manganese oxide. These disturbances are coupled with bioturbation by tree roots and termites. Two charcoals collected just above and below the bowl gave dating of $1166 \pm 30 \mathrm{BP}$ (Wk28110) and 1195士30 BP (Wk28111), respectively (Fig. 8). 

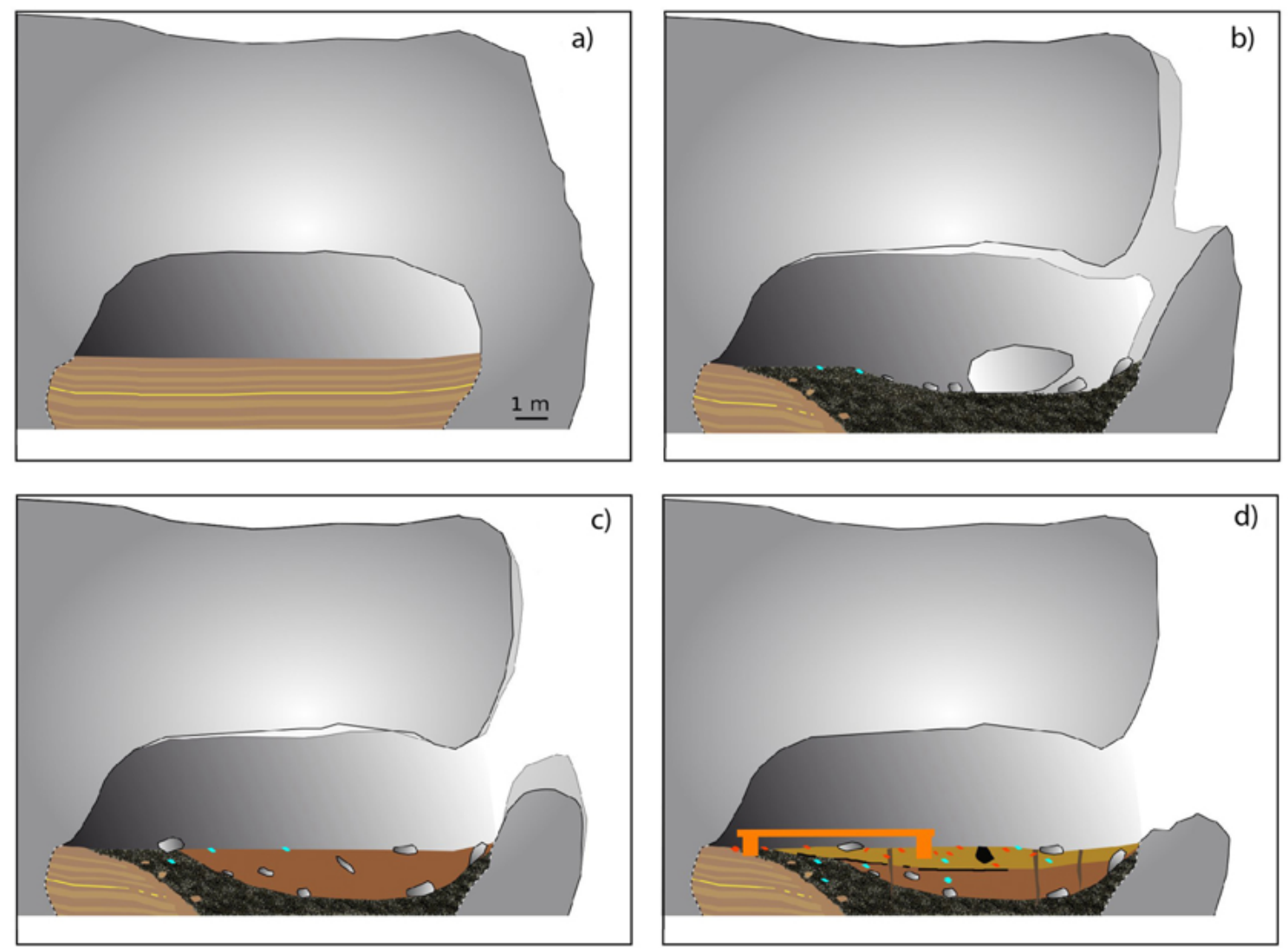

Fig. 7. Sedimentary process of Ngeubhinh Mouxeu rock-shelter: a: low energy sedimentation within a karstic cavity isolated by several meters of embedding limestone on the cliff side. Alternating episodes of weakly erosive events with remobilisation of ancient sediments and small fragments of limestone and fine sedimentation phases, under very low water flow; b: cracking/collapse of the embedding limestone on the cliff side, as a result of its progressive erosion by the action of atmospheric agents. Erosion of part of the sediments deposited during Phase I, over at least a thickness of $1.5 \mathrm{~m}$. Deposition of clayey sediments associated with rare gravels and a few lithic artefacts of "Paleolithic" facies. These sediments are probably a remobilisation of karst infills by run off from the top of the cliff; c: partial erosion of clay and gravels deposited during Phase II and deposition of red clay, probably resulting from the decalcification of the rock, containing some ceramic and lithic artefacts; d: deposition of silty-clayey sediments containing lithic artefacts and relatively abundant ceramics (dating back to Metal Age) and remains of finely fragmented human bones. These sediments have preserved the imprints of post-holes probably corresponding to the setting up of a wooden platform covering the soil of the rockshelter during one of the most recent periods of its occupation.
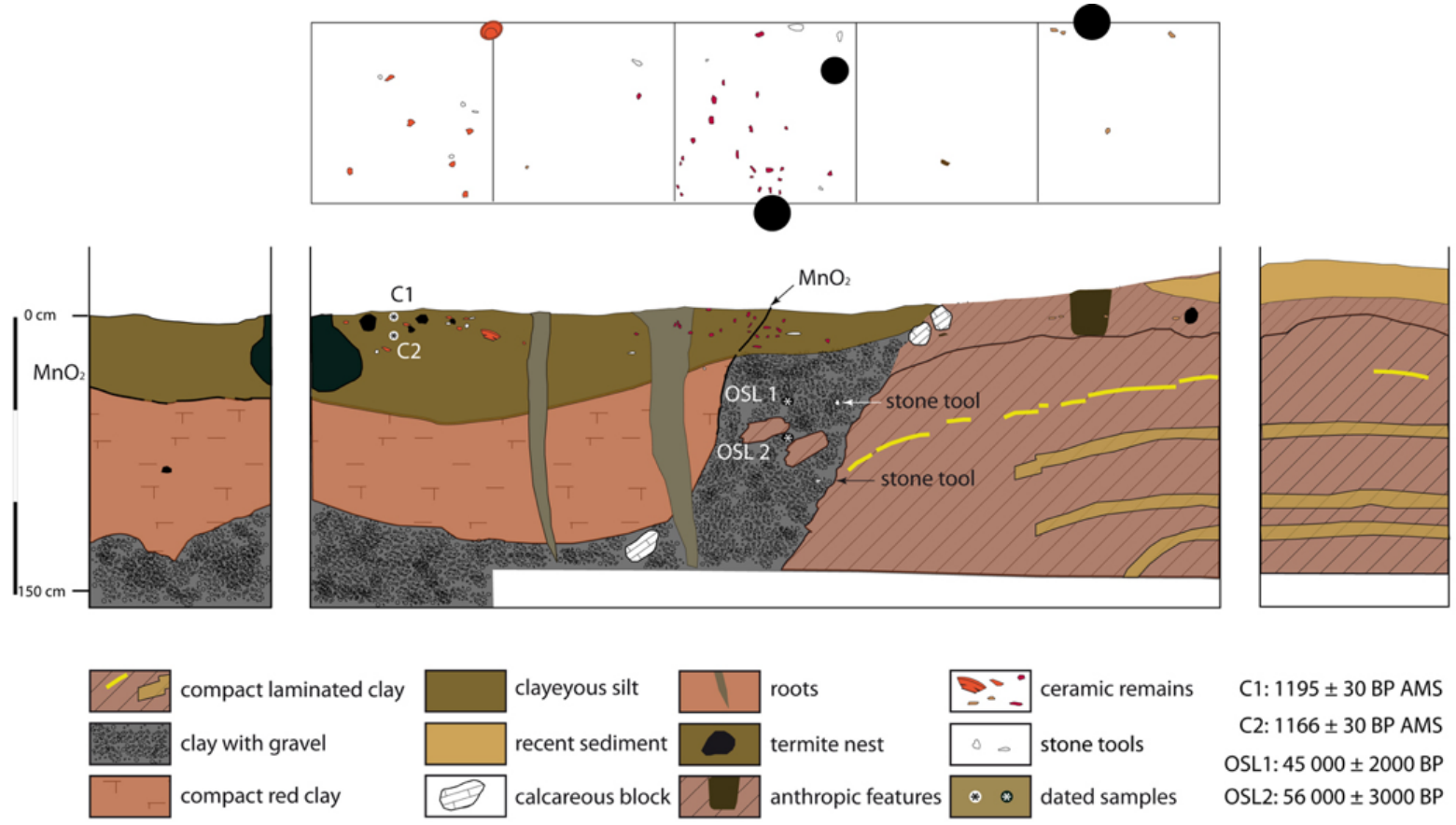

C1: $1195 \pm 30$ BP AMS

C2: $1166 \pm 30$ BP AMS

OSL1: $45000 \pm 2000 \mathrm{BP}$ OSL2: $56000 \pm 3000 \mathrm{BP}$

Fig. 8. Stratigraphy of the excavation of Ngeubhinh Mouxeu rock-shelter and surface mapping of the artefacts and features. 
A long span of occupation has already been reported (Sayavongkhamdy et al., 2000) at Tam Hua Pu (Luang Prabang province), the discovery of which was first published in the 1970s (Anzai, 1976). This site yielded

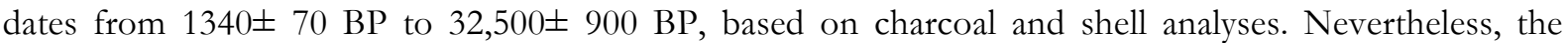
chronological series is not clearly linked to the archaeological artefacts; the authors (Sayavongkhamdy et al., 2000) only hypothesized that the Hoabinhian assemblage of Tam Hua Pu dated back to 4000 to 3500 BP without any clear supporting evidence. At the Ngeubhinh Mouxeu rock-shelter, the Hoabinhian stone tools were found out of stratigraphic context. Therefore, they can only be loosely related to a long span of time, ranging from $45,000^{\circ} \mathfrak{x} 2000 \mathrm{BP}$ by OSL to $1195^{\circ} \mathfrak{x} 30 \mathrm{BP}$ according to ${ }^{14} \mathrm{C}$ AMS dating. At Tham Vang Ta Leow (Luang Prabang province) the Hoabinhian industry was found to be more recent than $9770{ }^{\circ} x 50$ BP (White et al., 2009) as indicated by the dating of the layer at the bottom of the excavation.

\section{Conclusion}

By its central position between southern China, Vietnam and northern Thailand, the mountainous region of northern Laos should help shed new light on a prehistory that has received very little attention since the French colonial period. In mainland Southeast Asia, from Vietnam to Thailand, many Hoabinhian stone assemblages corresponding to hunter-gatherer sites have been excavated in karstic context. In the vicinity of northwestern Laos, northern Thai Hoabinhian sites have been dated from $3700 \pm 30 \mathrm{BP}$ at Huai Hin near the Salaween river (Forestier et al., 2005), and to 32,380 292 BP at Tham Lod in Mae Hong Son province (Shoocongdej, 2006). The expanse of land situated between the two well-documented regions corresponding of modern northern Thailand and Vietnam - the historical cradle of the Hobinhian culture (Colani, 1929a, 1929b) - is very likely to have been occupied over the same periods of time, in similar types of landscapes. More intensive and systematic prehistoric archaeological research should also make the connection with southern China as industries on cobbles with different knapping method exist at sites such as Chuang Dong (Forestier in Zeitoun et al., 2008) in the Guizhou province. Another question for which aclear regional framework is yet to be established concerns the precise modalities and determinants of the contact between the Hoabinhian world and the first pottery making cultures.

\section{Acknowledgments}

The whole material from the excavation of Ngeubihnh Mouxeu is kept at Luang Nam Tha Museum, thanks to the diligent assistance of Mr Mien Lorvankham. We would like to thank Mr Keothavy, Chady Soukaseum, Khamla, Chalou and Chako for their help and support while conducting the field work. We thank the two anonymous reviewers for their constructive comments. Funds for excavating and dating have been provided by the French ANR-AIRD program "Sédentarités autour du Mékong".

\section{References}

Anzai, M., 1976. Stone artifacts collected at prehistoric cave sites in Laos. Kokogaku Zasshi 61, 81-82.

Arambourg, C., Fromaget, J., 1938. Le gisement quaternaire de Tam Nang (Chaîne Annamitique septentrionale). Sa stratigraphie et ses faunes. C. R. Acad Sci. Paris 203, 793-795.

Colani, M., 1929a. Quelques paléolithes hoabinhiens typiques de l'abri sous-roche de Lang Kay. Bulletin de l'École Franc, aise d'Extrême-Orient 26, 353-384.

Colani, M., 1929b. Quelques stations hoabinhiennes (note préliminaire). Bulletin de l'École Franc $c_{s}$ aise d'Extrême-Orient 29, 261-272.

Colani, M., 1932. Champs de jarres monolithiques et de pierres funéraires du Tran-ninh (Haut Laos). In: Praehistorica Asiae Orientalis premier congrès des préhistoriens d'Extrême-Orient. Imprimerie d'ExtrêmeOrient, Hanoi, pp.103-128.

Colani, M., 1935. Mégalithes du Haut-Laos (Hua Pan, Tran Ninh). Publication de l'École Franc saise d'Extrême-Orient 25-26, Paris, 629 p.

Forestier, H., 2000. Chaînes opératoires lithiques en Asie du Sud-Est au Pléistocène supérieur final et au début de l'Holocène. L'Anthropologie 104, 531-548.

Forestier, H., Zeitoun, V., Seveau, A., Driwantoro, D., Winayalai, C., 2005. Prospections paléolithiques et perspectives technologiques pour redéfinir le Hoabinhien du Nord de la Thailande (campagnes 2002-2005). Aséanie 15, 33-60.

Fromaget, J., 1934. Observations et réflexions sur la géologie stratigraphique et structurale de l'Indochine. 
Bulletin du Service géologique d'Indochine 4, 101-164.

Fromaget, J., 1936. Sur la stratigraphie des formations récentes de la Chaîne annamitique septentrionnale et sur l'existence de l'homme dans le Quaternaire inférieur de cette partie de l'Indochine. C. R. Acad. Sci. Paris $16,738-741$.

Fromaget, J., 1937a. Études géologiques sur le Nord-Ouest du Tonkin et le Nord du Haut Laos-première partie. Bulletin du Service géologique d'Indochine 23, 101-164.

Fromaget, J., 1937b. Aperc u sur la stratigraphie et l'anthropologie préhistorique des formations récentes dans la Chaîne annamitique et le Haut-Laos. In: Compte rendu de la douzième session du Congrès préhistorique de France, Toulouse-Foix, pp. 785-798.

Fromaget, J., 1940a. Les récentes découvertes anthropologiques dans les formations préhistoriques de la Chaine annamitique. In: Proceedings of the Third Congress of Prehistorians of the Far East, Singapore 1938, pp. 51-59.

Fromaget, J., 1940b. La stratigraphie des dépôts préhistoriques de Tam Hang (Chaîne annamitique septentrionale) et ses difficultés. In: Proceedings of the Third Congress of Prehistorians of the Far East, Singapore 1938, pp. 60-70.

Fromaget, J., 1941. L'Indochine franc ${ }_{s}$ aise, sa structure, ses roches, ses mines et leurs relations possibles avec la tectonique. Bulletin du Service géologique d'Indochine 26, 1-140.

Fromaget, J., 1952. Études géologiques sur le Nord-Ouest du Tonkin et le Nord du Haut-Laos-première partie. Bulletin du Service géologique d'Indochine 19, 1-198.

Fromaget, J., Saurin, E., 1936. Note préliminaire sur les formations cénozoïques et plus récentes de la Chaîne annamitique septentrionale du haut Laos. Stratigraphie, préhistoire, anthropologie. Bulletin du Service géologique d'Indochine 22, 7-48.

Mansuy, H., 1920. Contributions à l'étude de l'Indochine. I. L'industrie de la pierre et du bronze dans la région de Luang Prabang (Haut-Laos). Imprimerie d'Extrême-Orient, Bulletin du Service géologique d'Indochine 7, Hanoi, 14 p.

Marwick, B., White, J.C., Bouasisengpaseuth, B., 2009. The Middle Mekong Archaeology Project and International Collaboration in Luang Prabang, Laos. The SAA Archaeological Record 9 (3), 25-27.

Massie, M., 1904. Catalogues des objets des âges de la pierre et du bronze recueillis dans la région de Luang Prabang. In: Pavie, Ernest, Leroux (Eds.), Mission Pavie Indo-chine 1879-1895. Recherches sur l'histoire naturelle de l'Indochine orientale, pp. 10-16.

Moser, J., 2001. Hoabinhian, Geographie und Chronologie eines steinzeitlichen Technocomplexes in Südostasien. Linden Soft, Köln,194 p.

Saurin, E., 1935. Station néolithique à Na Mou, Province de Luang Prabang (Haut-Laos) (Indochine franc, aise). In: Congrès préhistorique de France, Onzième session, Périgueux 1934, Compte-rendu 11, Paris, pp. 258-266.

Saurin, E., 1966. Le mobilier préhistorique de l'abri-sous-roche de Tam Pong (Haut Laos). Bulletin de la Société des Études d'Indochine 41, 106-118.

Saurin, E., 1968. Station préhistorique à ciel ouvert dans le massif du Pha Xieng Tong (Laos). In: Solheim, W. II. (Ed.), Anthropology at the Eight Pacific Science Congress, Social Science Research Institute, University of Hawaii, Honolulu. Asian and Pacific Archaeology Series no 2, pp. 86-95.

Sayavongkhamdy, T., Bellwood, P., Bulbeck, D., 2000. Recent archaeological research in Laos. Bulletin of the Indo-Pacific Prehistory Association 19, 101-110.

Shoocongdej, R., 2006. Late Pleistocene activities at the Tham Lot rockshelter in highland Pang Mapha, Mae Hong Son province, northwestern Thailand. In: Bacus E., Glover I., Pigott V. (Eds.), Uncovering Southeast Asia's Past, Singapore University Press, pp. 22-37.

Van Tan, H., 1985. Prehistoric pottery in Viet Nam and its relationships with Southeast Asia. Asian Perspectives 26, 135-146.

White, J.C., Bouasisengpaseuth, B., 2008. Archaeology of the Middle Mekong: Introduction to the Luang Prabang Exploratory survey. In: Goudineau, Y., Lorrillard, M. (Eds.), Recherches Nouvelles sur le Laos. École franc, aise d'Extrême Orient, Paris, pp. 37-52.

White, J.C., Lewis, H., Bouasisengpaseuth, B., Marwick, B., Arrell, K., 2009. Archaeological investigations in northern Laos: new contributions to Southeast Asian prehistory. Antiquity 83, 319 (project galery, 1 p). Zeitoun, V., Forestier, H., Nakbunlung, S., 2008. Préhistoires au sud du Triangle d’Or. Éditions IRD, Paris, $252 \mathrm{p}$. 